\title{
Study on the Marketing Strategy of Government Public Service Based on People's Livelihood Demand Orientation
}

\author{
Yan-Song $\mathrm{LI}^{1, \mathrm{a}}$, Wen-Qin JIANG ${ }^{2, b}$ \\ 1 School of Management, Shandong Institute of Business and Technology, Yantai,P.R. China, \\ 264005 \\ 2 School of Management, Shandong Institute of Business and Technology, Yantai,P.R. China, \\ 264005 \\ aemail: :jwq96@126.com , bemail: lys4021@sohu.com
}

Keywords: Government, 7p, Marketing strategy, Public service.

\begin{abstract}
Of view, the government's public service proposed the marketing idea and method to solve the problem of government public services, and the relevant model was established, using marketing strategies for the construction of a service-oriented government. $4 \mathrm{p}$ marketing mix including the following four elements: product, price, place, promotion. Any government department should design and choose according to their marketing mix of tar.
\end{abstract}

\section{Introduction}

The public services provided by government belong to the service marketing category, which need to use the idea and strategy of service marketing to strengthen the service consciousness and raise the service level and realizes the transformation from the management government to the service government in the end. The service marketing mix include the following seven elements: Product, Price, Place, Promotion, People, and Physical evidence and Process, Hereinafter referred to as 7p [1] Any department of government should design and select marketing mix according to own target client and service position, so that realize government's own goal comprehensively while satisfying the demand of society, enterprise and public effectively. [2 [3]

\section{Enhance Public Services to Meet the Needs of Citizens}

The government provides public products is an important part of the social redistribution. Product as service means all tangible or intangible factors that can meet people's needs. Designing the public service products should adhere to the people-oriented concept to meet the fundamental interests of the public really. The services that the government provides for public consist of anything that can meet the public demand, such as public goods, government regulations, government policies, the government image, the service environment created by the government, government planning and developing vision and so on. When the government provides public services, they must proceed from the objective needs of the public and pay close attention to the hierarchy of the citizens' needs. For a certain period, the citizens' demand level is closely related with the economic development, scientific and technological progress, social and cultural environment and other factors.[4]Today, public services people much-needed include employment, health, living environment, compulsory education, social security, public security, environmental protection and so on, especially some basic public services on the livelihood. At present, China adopted the mandatory supply of top-down decision-making mechanism for public goods, so that people are in urgent need of public services provided inadequate, but service products that are lack of "consumer demand preferences" are in excess supply, causing structural contradictions of public service highlight. One of the administrative ethics that public service-oriented government focuses on is response, the government should respond timely and effectively for the citizens' demand, and meet citizens' needs in a timely manner through designing targeted public products, and the government departments should not be separated from the actual level of the public needs and lead 
or lag blindly when they develop the relevant policies of the public service, otherwise people will not be able to identify with and accept to. As a result, the service performance of the government should see the public satisfaction evaluation as criterion and assess the work effectiveness of the government based on the "customer orientation", which means to build a performance evaluation system of public service-oriented government by seeing satisfaction as the core to ensure the quality of service.

\section{How to Reduce the Public to Accept the Cost of Public Services}

Price is a basic means of regulating the relationship between supply and demand, the decision should consider the product or service price formation process and factors, also want to consider pricing to achieve the goals and objectives. Price refers to the cost and pay in the process of the public using public goods and services, which includes both monetary expenditures and time, energy, physical loss in the process of obtaining service. Therefore, pricing is the basic means of regulating the supply and demand relationship, pricing decisions should consider not only the process of price formation, but also the objectives and methods of pricing. Because of the particularity of public goods, they often contain high transaction costs that even are difficult to measure, in order that the pricing of public goods is not easy to operate in practice. Perhaps it is good to adopt different pricing methods depending on the types of public goods: First, for pure public goods, that own economy scale and no "crowding effect" on consumption, such as public safety, law and order, environmental maintenance and so on, government pricing or financial compensation can be implemented suitably for free consuming for citizens. The cost of the service is from the government finances, which means to be shared by the whole society; Second, for quasi public goods, that are scramble and exclude on consumption, like city utilities, public education and health care services, it can be determined by the market mechanism to guide the rational allocation of resources, and implement the binding price formation mechanism guided by the government whose main feature is competitive, in order to constrain public bad or excessive consumption of public goods, and effectively prevent the "free-rider" problems.[5] In addition, while formulating the "service price", the government should give more consideration to the whole interests of the citizens and the social costs and returns. The total social cost refers to the government costs and customer costs. In order to reduce the cost of government and increase the cost of customers, the customer-oriented that does not comply with changes of the government should guide the trend of the times. The so-called customer-oriented means to establish government policies based on the customer's needs and measure the quality of public services based on the customer's satisfaction objectively. The most effective way to meet customers' needs is to minimize the cost of customers, which means to reduce the customer costs and pay in the process of using public goods and services. For this, the government should pay attention to the people, take full consideration of the public's economic ability to pay and the actual demand for energy, formulate corresponding beneficial and convenient policy for people, and ensure that the low-income, underprivileged class and the urban and rural marginalized groups can enjoy the services provided by the government. The most effective way to develop the public loyalty for the government is to try to reduce the price (customer costs) to zero, and adopting the measures, such as the administrative affairs, the on-site office, the e-government initiatives and so on, is an effective way to reduce the customer costs. Especially seamless e-government services can be contacted with the customer closely and directly, it can not only provide customers with the required personalization options and diversity of participation and better meet customers' demands of higher level, but also reduce unnecessary and direct contact of the government departments and the customers, in order to avoid bureaucracy, multi tiered buck each, cumbersome, documents travel and many other issues, and eliminate the customer cost of using public goods and services in maximum extent 


\section{Raise the Public Enjoyment of the Convenience of Service}

Public goods channel optimization can improve the efficiency of product supply comprehensively, reduce the service cost of public products, and improve the convenience of public enjoying the service.

\section{Channel Design for Flat}

Channel is refers to the government public products and service and submit it to the target public by the way. The government should make it streamline as much as possible in the process of setting service agencies and assigning personnel refining, implement the decentralization of rights, regulatory relaxation and process optimization, simplify, reduce the levels, increase outlets and provide "one-stop" service as far as possible. We should make full use of modern scientific and technological means to provide low-cost and Internet service across time and space, ensure that the service is timely and accurate, and improve the convenience of public enjoying the government services. E-government can accomplish a great deal in this regard, higher levels of government can sent orders of information supply directly to the government service terminal that can face public directly through e-government, for example, the G2B business of the e-government, through the government tax system network enterprises can complete tax registration, tax declaration, the taxes allocation, querying the Tax Bulletin, understanding the tax policy and other business in the offices, which can be convenient and reduce expenses. For example, the Sweden Social Security Commission used telephone to provide services to the public in the past and charge 30 SEK by each telephone service, but after using online services, only 3 SEK is charged at each time to reduce costs for users and bring the whole performance improvement and customer satisfaction.

\section{To Design Differentiation in the Channel Implement Mode}

The complexity of public goods and services makes it difficult for the government alone to provide adequate public services. Therefore, to break through all the social and public services supply functions carried by the government and to adapt to the characteristics of different public goods, public sector, private sector and the third sector (non-governmental non-profit sector) should cooperate with each other based on the statutory rules and deal with social and public affairs together, in order to achieve "good governance", form the public service diversified supply system of "government-led, public-private competition".[6] On one hand, we should speed up the construction of public service-oriented government, strengthen the government's main channel position in the supply of public goods, give full play to the government's coordination, service, specification and supervisory, fully discharge its public management functions; On the other hand, we should promote the market-oriented reforms of the public service actively, learn from the practices of the West, and while strengthening macro-control of the delivery of public services, we can introduce the competition mechanism to the field of public service at the same time, open up some of the public service markets, allow and encourage the private sectors to enter the field of public service within a certain range, promote the ways of public goods supply to transform from a single government-led government to a market participating one, and achieve supply cost reduction and efficiency optimization through the introduction of competition mechanism, and reach the satisfaction of the public service through the exercise of the option.

\section{Realize the Effective Communication}

\section{Policy Marketing and Promotion}

The government and public administration achieve the effective integration of GI(geographical identification), HI (humanities identification), PI(policy identification)and SI (industry identification) through public service, in order to make the government's public service and policy ideas generally accepted by the public. [5] Through every possible way of advertising, publicity and public relations, government decisions or advocates should be introduced to the public, introducing the service content provided by the agencies or departments, operational processes, ways of 
working, job functions, work rules, institutions set and so on, make the public understand the government policies or agree with the government's vision, obtain the understanding and support of the public in the maximum degree and accept government services better. Through the establishment of effective communication channels and mechanisms, it can be made truly open, fair and transparent, in order to make the public accept the government's product smoothly and response to the government's claims and demands timely. The government establishes a good image of the government, improve the government's credibility and reputation through the feedback of the public opinions, accepting public rationalization proposals and conducting public relations. At the same time, he should promote and practice the system of government pledges.

\section{The Shape or Revised Government Image}

Good government image is to obtain the necessary condition of widely accepted by the public. Government must be from inside to outside gradually improve in order to enhance image, In general, Can through the mass media dissemination, consumer word of mouth, press conference, government affairs public, or for a social impact is bigger events held public hearings and other approaches to image promotion, Create a range of social credibility and reputation.

The people refer to all levels of the government officials, who are executors of the government's public service and have direct relations to the service quality. The government officials should take "serve for the people" as the highest objective and take customers as our Gods, avoid traditional "the officialdom standard" consciousness, and must shift from the past "gives orders" to the "service provider". For this, such rules and regulations as service standard, door-to-door service system, the inquiry system and government-public relation management system and so on should be established to raise public satisfaction.

\section{Show "We Can Provide High Quality and Quick Service"}

Government's service is intangible. Government enables the public perceive the service quality through such physical appearance as the entity environment, the facility, officials' appearance, the work equipment and other visible reality clues. For example, creating the warmly, considerate and neat service environment, training warm-hearted service attitude officials, adopting modern service equipment and so on make the public satisfactory.

\section{Take Customer Satisfaction as the Highest Objective and Appraisal Criterion of Government Operation}

The process refers to both the delivery process of government providing the service for the customer and the experience of public enjoying service, which is one of service quality elements. Therefore, if government pursues total quality management, any department must pay more attention to the service process management and take customer satisfaction as the highest objective and appraisal criterion of government operation [7]. For instance, when one department accepts the public visit, the officials must listen attentively to the customer' statement, explains the customer' inquiry in detail and deliver the materials for the customer joyfully and pleasant and so on.

\section{Conclusions}

Marketing as a organization under the environment of market economy benign operation mode, do not belong to enterprise or private product patents. Since it is the government of public service to the public to provide products, It also has the property of marketing, That is, the social public is public service consumers, government agencies, customers, So government also can according to own ability to make money and resources reasonable guide requirements.[8] Service is the essence of the government; service-oriented government is a brand new idea and value orientation. Government in modern society should be skillful at using concepts, methods and techniques of 
marketing management to realize the real transformation from management-oriented government to service-oriented government.

\section{Acknowledgement}

This work is supported by Shandong Social Science Foundation of China (No. 16CCXJ08).

\section{References}

[1] Jing ZHU . Value Analysis and System Construction of Government Marketing [J]. Administrative Tribune, 2009(5): 12-14. (In Chinese)

[2] Wen-wang XIAO, Government Meeds Marketing [J]. Commercial Research, 2002(1): 92-95. (In Chinese)

[3] Dong-ling CHEN, SU Chao-hui. 0n 4C's Mix of Government marketing [J]. Commercial Times, 2008(30): 8-9. (In Chinese)

[4] Yan ZHOU. Thoughts on Goveronment's Marketing Strategies [J]. Consumer Guide, 2008(9):99. (In Chinese)

[5] Wei YU, CHEN Yong-hua. SWOT Analysis on Marketing of Government's Public Goods [J]. Jiangsu Commercial Forum, 2008(3): 75-77.(In Chinese)

[6] Elinor Ostrom: Covering the Commons-The Evolution of Institutions for collective Action, Cambridge University Press.1990.

[7] Dong-ling CHEN, SU Chao-hui. 0n 4C's Mix of Government marketing, Commercial Times, 2008(30): 8-9. (In Chinese)

[8] [U.S] Philip.Kotler, National Marketing[M]. Beijing: China Press, 2003: 130-175. 